The Open Dentistry Journal
CrossMark
Content list available at: www.benthamopen.com/TODENTJ/
DOI: $10.2174 / 1874210601711010120$

REVIEW ARTICLE

\title{
Peripheral Solitary Osteoma of the Zygomatic Arch: A Case Report and Literature Review
}

\author{
Thomas Starch-Jensen* \\ Department of Oral and Maxillofacial Surgery, Aalborg University Hospital, Aalborg, Denmark
}

Received: November 18, 2016

Revised: January 05, 2017

Accepted: January 23, 2017

\begin{abstract}
Osteoma is a benign slow-growing osteogenic neoplasm commonly occurring in the craniofacial skeleton, characterized by the proliferation of compact and/or cancellous bone. Osteomas may be peripheral, central, or extraskeletal. Peripheral osteomas arise from the periosteum and are quite uncommon in the jaw bones. The exact aetiology and pathogenesis of peripheral osteoma are unknown. Clinically, peripheral osteomas are usually asymptomatic, but depending on the location and size of the lesion, it may cause swelling, pain, esthetic disfigurement and functional impairment. On radiological imaging, a peripheral osteoma appears often as well-circumscribed, round to oval, pedunculated radiopaque mass attached to the cortex by a broad base or a pedicle. Asymptomatic osteomas are treated conservatively, while surgical excision is indicated when the lesion is symptomatic, actively growing, or for cosmetic reasons. Histologically, osteomas are composed of a normal-appearing, dense mass of lamellar bone. Recurrence of peripheral osteoma after surgical removal is extremely rare and there are no reports of malignant transformation. A review of the literature disclosed only 7 well-documented cases of peripheral osteoma located at the zygomatic bone. The purpose of this article is to present the clinical, radiographic, surgical and histological features of a solitary peripheral osteoma of the left zygomatic arch in a 55-year-old woman and to review the literature about this uncommon pathologic entity.
\end{abstract}

Keywords: Dentistry, Diagnostic imaging, Facial bones, General surgery, Neoplasms, Osteoma.

\section{INTRODUCTION}

Osteoma is a benign slow growing neoplasm characterized by the proliferation of compact or cancellous bone, and one of the most common tumors of the nose and paranasal sinuses [1]. It was first recognized as a tumor by Jaffe in 1935 [2]. Multiple osteomas are mainly associated with Gardner's syndrome while solitary osteomas can be further classified based on the location as: (1) the central osteoma arising from the endosteum; (2) the peripheral osteoma deriving from the periosteum and (3) the extraskeletal soft tissue osteoma, which usually develops within the muscles [2]. The etiology of the osteoma has not been established, but several explanations have been suggested for the origin of these neoplasms such as osteogenic, traumatic, and infective sources [1]. Females present a higher incidence rate without predilection for any specific age range [3]. The majority of osteomas are peripheral, while central osteomas in the craniofacial skeleton are uncommon [4]. Peripheral osteomas in general present as a solitary, slowly and asymptomatic continuous growing hard mass protruding from the periphery of the surface of bone [5]. Osteoma in the facial skeleton is often detected incidentally on routine radiographic examination or when it causes facial asymmetry, pain, limitation or deviation of the mandible on opening, or dysfunction [6 - 8]. Radiographically, peripheral osteomas usually present as a round or oval well-circumscribed radiopaque bone-thickening lesion whose base is united with the underlying cortical bone, often as a pedunculated lesion but may also have a broad-base [7]. The slow growth of an osteomas justified a conservative approach toward an asymptomatic lesion, whereas surgical removal of osteomas is indicated when the lesion is symptomatic, actively growing, or causing esthetic disfigurement and functional impairment. Histopathologically, the compact osteomas comprises of dense, compact bone with a few marrow spaces

\footnotetext{
* Address correspondence to this author at the Department of Oral and Maxillofacial Surgery, Aalborg University Hospital, 18-22 Hobrovej, DK-9000 Aalborg, Denmark; Tel: +45 976627 98; Fax: +45 976628 25; E-mail: thomas.jensen@rn.dk
} 
and with only a few osteons [8]. Osteons are the structural unit of compact bone consisting of concentric layers, or lamellae, of compact bone tissue that surround the haversian canal. The cancellous osteoma is characterized by bony trabeculae and a fibro fatty marrow enclosing osteoblast and with architecture resembling mature bone [8]. Osteoma is a benign tumor with low tendency to recur when treated by an adequate surgical technique [8]. Although surgical excision is recommended for growing symptomatic osteomas, there are no reports of malignant transformations in reviewed literature in English language [8].

The purpose of presenting this case report is to increase the number of reported cases of zygomatic osteomas and to summarize the current knowledge of this uncommon maxillofacial lesion.

\section{CASE PRESENTATION}

A 55-year-old woman was referred to the Department of Oral and Maxillofacial Surgery, Aalborg University Hospital, Denmark, due to a long-lasting increasing dull pain from the left side of her face. There was no previously history of facial trauma and her medical history did not contain any known pathology of the intestines.

Extraorally, a discrete swelling was observed anterior to the left temporomandibular joint. There were no signs of inflammation. The temporalis and masseter muscles were tender on palpation, with normal range of motion. Intraorally, the patient was edentulous with well-functioning removable prosthesis. A panoramic radiographic exam showed the presence of a pedicled osseous lesion originating from the left zygomatic arch (Fig. 1). A cone beam computed tomography confirmed the presence of a $1.2 \times 1.4 \mathrm{~cm}$ well-circumscribed radiopaque structure located on the lateral border of the left zygomatic arch (Fig. 2). On the basis of the clinical and radiographic findings, a working diagnosis of peripheral osteoma of the zygoma arch was made. Due to increasing pain and cosmetic reasons, the decision was made to surgically remove the tumor.

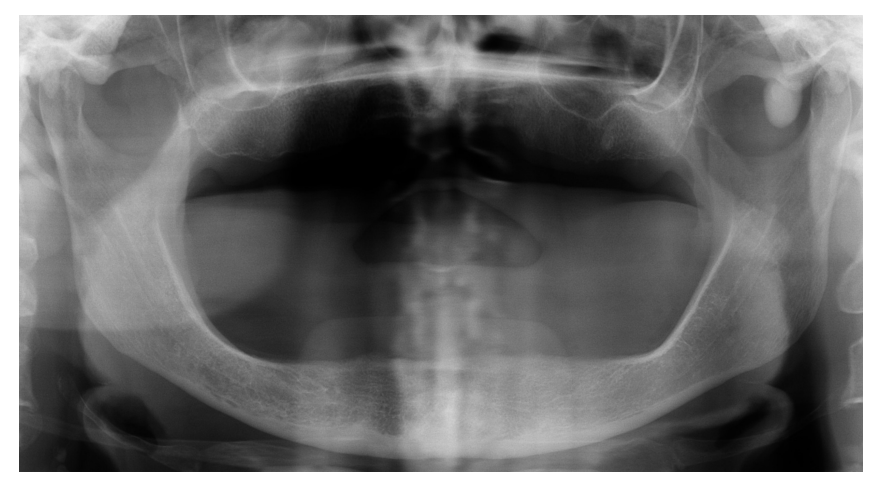

Fig. (1). Panoramic radiographic visualizing a pedunculated osseous lesion originating from the left zygomatic arch.

(A)

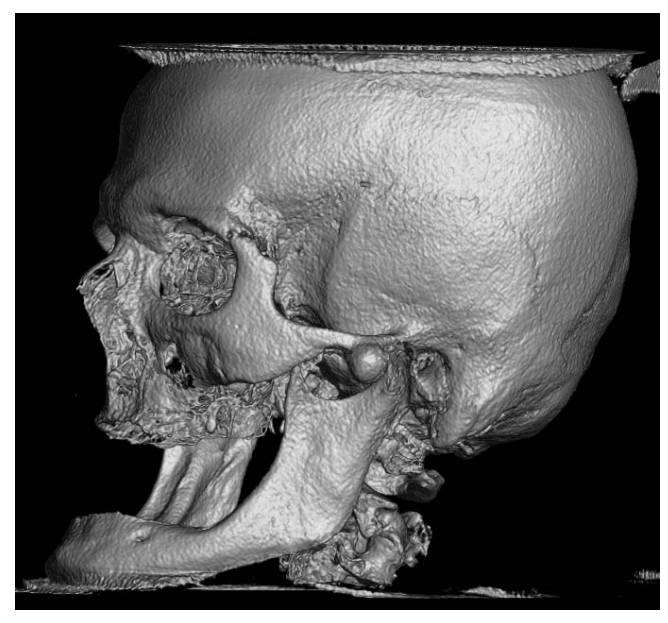

(B)

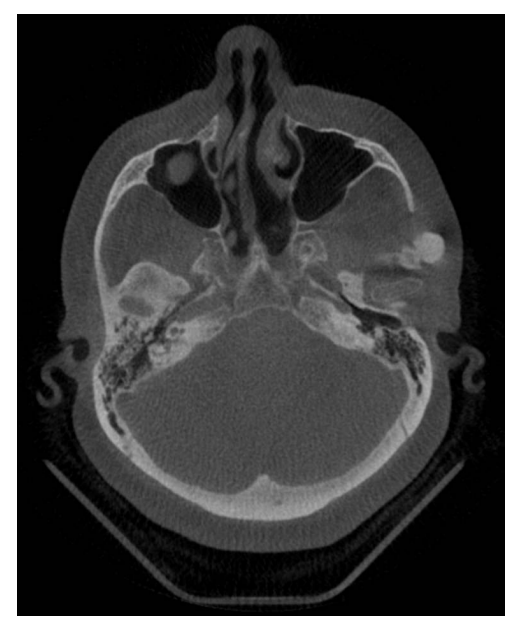

Fig. (2). Cone Beam Computed Tomography scan. (A) Axial image showing a round well-circumscribed radiopaque lesion originating from the lateral surface of the left zygomatic arch. (B) Three-dimensional reconstruction image visualizing a wellcircumscribed radiopaque structure located on the lateral border of the left zygomatic arch. 
In general anaesthesia, a preauricular incision through the skin and subcutaneous connective tissue was performed. The tissue was reflected by blunt dissection above the zygomatic arch to the level of the superficial layer of the temporalis fascia. The superficial temporal vessels were retracted anteriorly with the skin flap and nerve stimulator was used during the surgical procedure to detect branches of the facial nerve. After incision of the superficial temporal fascia over the zygomatic arch and dissection of the periosteum from the lateral portion of the zygomatic arch, a complete view of the lesion was obtained and the temporal branch of the facial nerve was carefully protected with a retractor within the superficial layer of the temporalis fascia. The pedunculated bony structure was removed with bur and chisel (Fig. 3). Finally, surgical recontouring of the zygomatic arch was performed (Fig. 4). Healing was uneventful. Histopathologic examination revealed a well-circumscribed mass composed of dense lamellar bone, compatible with osteoma.

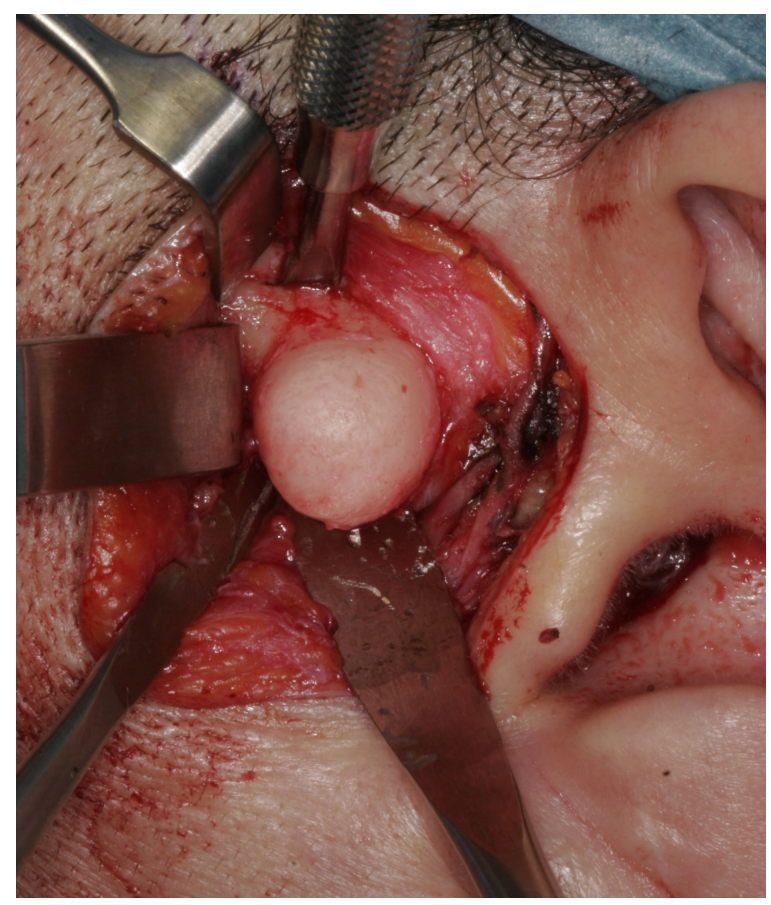

Fig. (3). Intraoperative clinical photo of the exposed peripheral osteoma on the zygomatic arch.

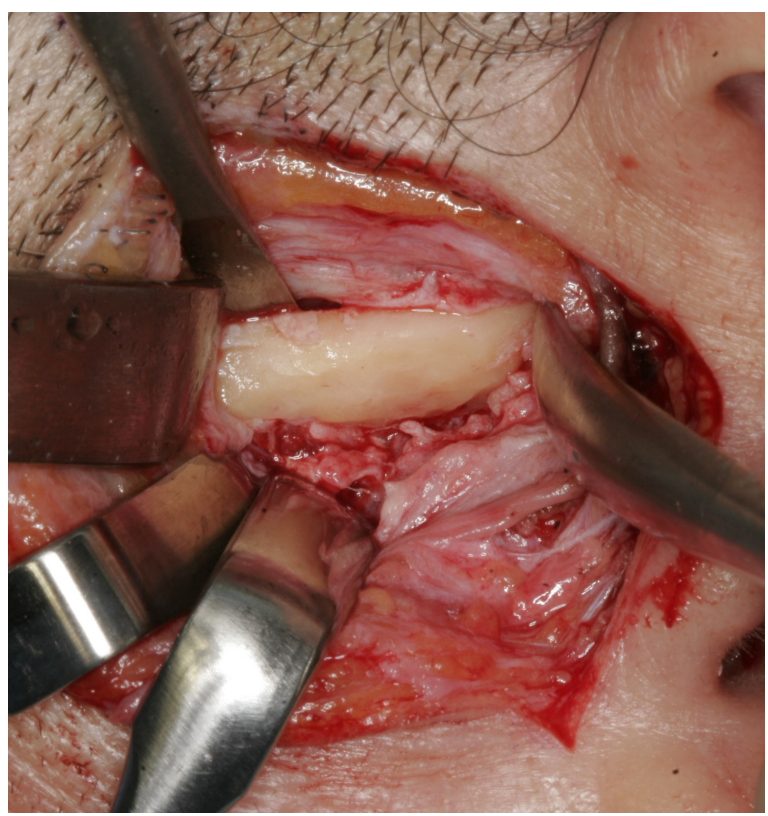

Fig. (4). Intraoperative clinical photo after resection of the peripheral osteoma and recontouring of the zygomatic arch. 
There was no clinical or radiographic evidence of recurrence on the one year follow-up examination (Fig. 5). The patient had normal neurovascular function, but minor pain from her temporomandibular joint and muscles persisted.

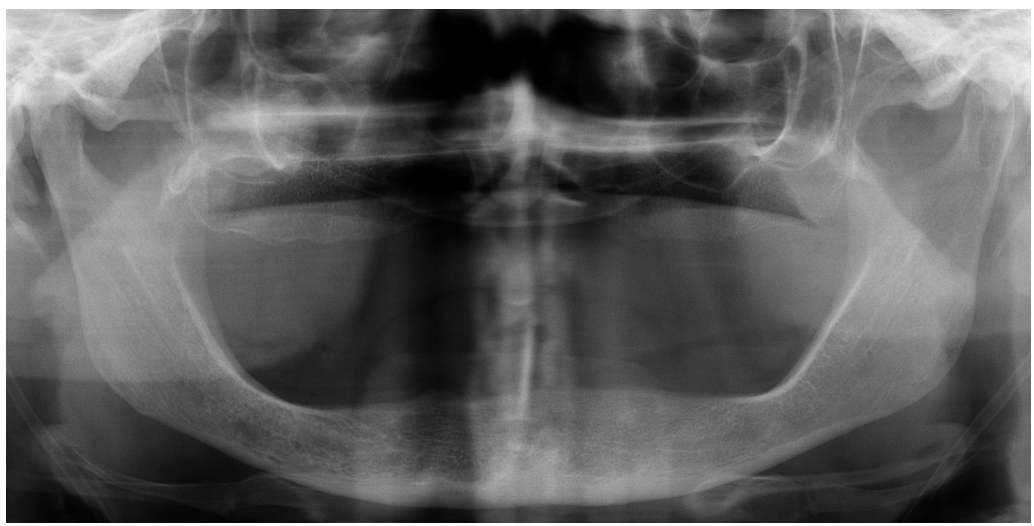

Fig. (5). Panoramic radiographic after one year disclosing no recurrence of the peripheral osteoma on left the zygomatic arch.

Table 1. Clinical features of 7 previous published cases of zygoma osteoma.

\begin{tabular}{|c|c|c|c|c|c|c|c|c|c|}
\hline Case & $\begin{array}{c}\text { Age/ } \\
\text { Gender }\end{array}$ & $\begin{array}{c}\text { Clinical } \\
\text { symptoms }\end{array}$ & $\begin{array}{c}\text { Radiographic } \\
\text { findings }\end{array}$ & Treatment & Complications & $\begin{array}{c}\text { Histopathological } \\
\text { examination }\end{array}$ & Follow-up & Relapse & References \\
\hline 1 & $25 / \lesssim$ & $\begin{array}{l}\text { Restricted } \\
\text { mandibular } \\
\text { opening }\end{array}$ & $\begin{array}{l}\text { Pedunculated } \\
\text { osseous lesion } \\
\text { medial to the } \\
\text { zygomatic arch }\end{array}$ & $\begin{array}{l}\text { Surgical } \\
\text { resection by } \\
\text { intraoral } \\
\text { approach }\end{array}$ & $\begin{array}{l}\text { Healing was } \\
\text { uneventful }\end{array}$ & $\begin{array}{l}\text { Normal bone with } \\
\text { medullary fibrosis }\end{array}$ & 8 weeks & No & $\begin{array}{l}\text { Boland et al., } \\
1983 \text { [9] }\end{array}$ \\
\hline 2 & $55 / 9$ & $\begin{array}{l}\text { Left ear was } \\
\text { closing }\end{array}$ & $\begin{array}{l}\text { Pedunculated } \\
\text { osseous lesion lateral } \\
\text { to the zygomatic } \\
\text { arch }\end{array}$ & $\begin{array}{l}\text { Surgical } \\
\text { resection by } \\
\text { extraoral } \\
\text { approach }\end{array}$ & $\begin{array}{l}\text { Healing was } \\
\text { uneventful }\end{array}$ & Normal cortical bone & ND & ND & $\begin{array}{l}\text { Furlaneto et al., } \\
2004[10]\end{array}$ \\
\hline 3 & $20 / \delta$ & $\begin{array}{l}\text { Itchy facial } \\
\text { swelling }\end{array}$ & $\begin{array}{l}\text { Pedunculated } \\
\text { osseous radiopaque } \\
\text { mass on the zygoma }\end{array}$ & $\begin{array}{l}\text { Surgical } \\
\text { resection by } \\
\text { extraoral } \\
\text { approach }\end{array}$ & $\begin{array}{l}\text { Healing was } \\
\text { uneventful }\end{array}$ & $\begin{array}{l}\text { Dense compact bone } \\
\text { with sparse marrow }\end{array}$ & 6 months & No & $\begin{array}{l}\text { Akinmoladun et } \\
\text { al., } 2007 \text { [11] }\end{array}$ \\
\hline 4 & $61 / 9$ & None & $\begin{array}{l}\text { Pedunculated } \\
\text { osseous lesion on the } \\
\text { zygomatic arch }\end{array}$ & Observation & ND & Not performed & ND & ND & $\begin{array}{l}\text { Durao et al., } \\
2012[12]\end{array}$ \\
\hline 5 & $62 / \delta$ & $\begin{array}{l}\text { Pain and } \\
\text { tenderness }\end{array}$ & $\begin{array}{l}\text { A well-defined } \\
\text { circular radiolucent } \\
\text { lesion at the zygoma }\end{array}$ & $\begin{array}{l}\text { Surgical } \\
\text { resection by } \\
\text { extraoral } \\
\text { approach }\end{array}$ & ND & $\begin{array}{l}\text { Well-vascularized } \\
\text { stroma and immature } \\
\text { bone }\end{array}$ & ND & ND & $\begin{array}{l}\text { Mintz et al., } \\
2013[13]\end{array}$ \\
\hline 6 & $32 / 9$ & $\begin{array}{l}\text { Painful } \\
\text { swelling }\end{array}$ & $\begin{array}{l}\text { Firm bony swelling } \\
\text { above the zygomatic } \\
\text { arch }\end{array}$ & $\begin{array}{l}\text { Surgical } \\
\text { resection by } \\
\text { extraoral } \\
\text { approach }\end{array}$ & $\begin{array}{l}\text { Healing was } \\
\text { uneventful }\end{array}$ & $\begin{array}{l}\text { Cancellous-type } \\
\text { osteoma }\end{array}$ & 7 years & No & $\begin{array}{l}\text { Quintans et al., } \\
2013 \text { [14] }\end{array}$ \\
\hline 7 & $41 / \delta$ & $\begin{array}{l}\text { Painless firm } \\
\text { mass }\end{array}$ & $\begin{array}{l}\text { Lobulated bony } \\
\text { mass protruding } \\
\text { from outer cortex of } \\
\text { the zygoma }\end{array}$ & $\begin{array}{l}\text { Surgical } \\
\text { resection by } \\
\text { intraoral } \\
\text { approach }\end{array}$ & $\begin{array}{l}\text { Healing was } \\
\text { uneventful }\end{array}$ & $\begin{array}{l}\text { Normal mature } \\
\text { compact bone }\end{array}$ & 1 month & No & $\begin{array}{l}\text { Kim et al. } 2015 \\
{[15]}\end{array}$ \\
\hline
\end{tabular}

Abbreviations: ND: no data.

\section{DISCUSSION}

We present a 55 years old woman with a peripheral zygomatic osteoma and summarize the current knowledge about this uncommon benign osteogenic neoplasm. Peripheral osteomas are common in the craniofacial region, while osteoma of the zygoma is extremely uncommon. A search of the literature identified only 7 well-documented cases of peripheral osteomas of the zygoma (Table 1) [9 - 15]. The majority of these cases display as a well-defined circular pedunculated radiopaque osseous lesion origination from either the zygomatic bone or arch. Peripheral osteoma in the facial skeleton is often detected incidentally on routine radiographic examination due to an asymptomatic slow growth rate. However, only one of the previous cases was found incidentally in relation to a radiological examination prior to installation of dental implants [12]. All the other cases was examined due to either pain, swelling, facial asymmetry, cosmetic disfigurement or functional impairment, but in some of the reported cases, the peripheral osteoma has debuted several 
years earlier and recently increased in size $[11,14]$. Hence, the actual symptoms should not be related to the growth of the peripheral zygomatic osteoma, but more likely to the compression from the lesion to the adjacent anatomical structures, which is in accordance with the symptoms of our case.

Usually, a conventional radiograph is sufficient to make a diagnosis of a peripheral osteoma, but computed tomography with three-dimensional reconstruction is the best imaging modality for precise localization of the osteoma and treatment planning prior to surgical removal. An individualized approach for the management of osteomas is recommended considering the size and location of the tumor. Smaller asymptomatic peripheral osteomas generally do not require any treatment, whereas surgical intervention is indicated when the lesion is larger, symptomatic, actively growing or causes functional impairment. Surgical removal of a peripheral zygomatic osteoma by an intraoral approach is desirable since it avoids facial scarring but the ease of accessibility is limited. Therefore, an extraoral approach is frequently used. However, the decision regarding the type of surgical approach should depend upon the anatomical location of the osteoma, risk of complications and cosmetic patient demands. Consequently, the surgical approach to remove a peripheral osteoma of the zygoma should be case specific and the intraoral approach is preferable when possible, mainly for cosmetic reasons [16]. Surgical treatment of a symptomatic osteoma consists of complete removal at the base where it unites with the cortical bone and recurrence of peripheral osteomas of the zygoma after surgical excision is rare, with a single case occurred 10 years after surgical treatment [15]. There are no reports of malignant transformation of peripheral osteoma in reviewed literature in English language, but regular clinical and radiographic follow-up examination is advised.

Clinically, peripheral osteoma should be differentiated from several pathologies, such as exostoses, osteoblastoma, osteoid osteoma, late-stage central ossifying fibroma or complex odontoma [17].

The presence of craniofacial osteomas may be a sign of the presence of Gardner's syndrome which is an autosomal dominant syndrome characterized by the presence of polyps in the gastrointestinal area, several osteomas of the skull and face, soft tissue tumors, skin tumors, and supernumerary multiple impacted teeth. Since the osteomas develop before the colorectal polyposis, early recognition of the syndrome is very important to the prognosis of the disease [16]. Therefore, General Dental Practitioners should be aware of Gardner's syndrome if they diagnose a patient with impacted teeth and osteomas of the jaws.

In this case, surgical resection performed was completely effective and no complications with the pre-auricular approach have been observed after a follow-up of one year.

\section{CONCLUSION}

A case of a solitary peripheral zygomatic osteoma has been presented and the current knowledge about this uncommon entity has been discussed. The clinical and radiographic appearance of a solitary peripheral osteoma of the zygoma is very characteristic. The present case was not part of Gardner syndrome since no pathology of the intestines or impacted teeth was discovered. The association of osteoma with Gardner's syndrome must always be kept in mind and General Dental Practitioners should have knowledge of this serious disease.

\section{CONFLICT OF INTEREST}

The author confirms that this article content has no conflict of interest.

\section{ACKNOWLEDGEMENTS}

Declared none.

\section{REFERENCES}

[1] Boffano P, Roccia F, Campisi P, Gallesio C. Review of 43 osteomas of the craniomaxillofacial region. J Oral Maxillofac Surg 2012; 70(5): 1093-5.

[http://dx.doi.org/10.1016/j.joms.2011.05.006] [PMID: 21820784]

[2] Jaffe HL. Osteoid osteoma: a benign osteoblastic tumor composed of osteoid and atypical bone. Arch Surg 1935; 31: 709-28. [http://dx.doi.org/10.1001/archsurg.1935.01180170034003]

[3] Dell'Aversana Orabona G, Salzano G, Iaconetta G, et al. Facial osteomas: fourteen cases and a review of literature. Eur Rev Med Pharmacol Sci 2015; 19(10): 1796-802.

[PMID: 26044223]

[4] Larrea-Oyarbide N, Valmaseda-Castellón E, Berini-Aytés L, Gay-Escoda C. Osteomas of the craniofacial region. Review of 106 cases. J Oral 
Pathol Med 2008; 37(1): 38-42.

[http://dx.doi.org/10.1111/j.1600-0714.2007.00590.x] [PMID: 18154576]

[5] Sayan NB, Uçok C, Karasu HA, Günhan O. Peripheral osteoma of the oral and maxillofacial region: a study of 35 new cases. J Oral Maxillofac Surg 2002; 60(11): 1299-301. [http://dx.doi.org/10.1053/joms.2002.35727] [PMID: 12420263]

[6] Ogbureke KU, Nashed MN, Ayoub AF. Huge peripheral osteoma of the mandible: a case report and review of the literature. Pathol Res Pract 2007; 203(3): 185-8.

[http://dx.doi.org/10.1016/j.prp.2007.01.004] [PMID: 17307307]

[7] Herford AS, Stoffella E, Tandon R. Osteomas involving the facial skeleton: a report of 2 cases and review of the literature. Oral Surg Oral Med Oral Pathol Oral Radiol 2013; 115(2): e1-6.

[http://dx.doi.org/10.1016/j.oooo.2011.09.033] [PMID: 22738720]

[8] Johann AC, de Freitas JB, de Aguiar MC, de Araújo NS, Mesquita RA. Peripheral osteoma of the mandible: case report and review of the literature. J Craniomaxillofac Surg 2005; 33(4): 276-81. [http://dx.doi.org/10.1016/j.jcms.2005.02.002] [PMID: 15979316]

[9] Boland T, Ross Beirne O. Zygomatic exostosis. Int J Oral Surg 1983; 12(2): 124-6. [http://dx.doi.org/10.1016/S0300-9785(83)80009-X] [PMID: 6409825]

[10] Furlaneto EC, Rocha JR, Heitz C. Osteoma of the zygomatic archreport of a case. Int J Oral Maxillofac Surg 2004; 33(3): 310-1. [http://dx.doi.org/10.1006/ijom.2002.0468] [PMID: 15287318]

[11] Akinmoladun VI, Akadiri AO, Olusanya AA. Peripheral osteoma of the zygoma: literature review and case presentation. Afr J Med Med Sci 2007; 36(4): 381-3. [PMID: 18564657]

[12] Durão AR, Chilvarquer I, Hayek JE, Provenzano M, Kendall MR. Osteoma of the zygomatic arch and mandible: Report of two cases. Rev Port Estomatol Med Dent e Cir Maxilofac 2012; 53: 103-7.

[13] Mintz S, Velez I. Osteoid osteoma of the zygoma: report of an unusual case. J Am Dent Assoc 2007; 138(6): $793-7$. [http://dx.doi.org/10.14219/jada.archive.2007.0267] [PMID: 17545268]

[14] Quintans AD, Castro JA, Machado PE, Costa FW. Solitary osteoma in the zygomatic arch. J Craniofac Surg 2013; 24(6): 2209-10. [http://dx.doi.org/10.1097/SCS.0b013e31829a84ba] [PMID: 24220448]

[15] Kim DY, Oh KS. A rare case of peripheral osteoma of the zygoma. Arch Plast Surg 2015; 42(1): $103-5$. [http://dx.doi.org/10.5999/aps.2015.42.1.103] [PMID: 25606503]

[16] Hu W, Thadani S, Agrawal M, Sharma N, Tailor S. Peripheral osteoma of the palate: report of a case and review of literature. J Clin Diagn Res 2014; 8(12): ZC29-31.

[17] Dalambiras S, Boutsioukis C, Tilaveridis I. Peripheral osteoma of the maxilla: report of an unusual case. Oral Surg Oral Med Oral Pathol Oral Radiol Endod 2005; 100(1): e19-24.

[http://dx.doi.org/10.1016/j.tripleo.2005.03.011] [PMID: 15953906]

(C) 2017 Thomas Starch-Jensen

This is an open access article distributed under the terms of the Creative Commons Attribution 4.0 International Public License (CC-BY 4.0), a copy of which is available at: https://creativecommons.org/licenses/by/4.0/legalcode. This license permits unrestricted use, distribution, and reproduction in any medium, provided the original author and source are credited. 